\title{
Inheritance in Human Dizygotic Twinning
}

\section{Citation}

White, Colin, and Grace Wyshak. 1964. "Inheritance in Human Dizygotic Twinning." N Engl J Med 271 (19) (November 5): 1003-1005. doi:10.1056/nejm196411052711908.

\section{Published Version}

doi:10.1056/NEJM196411052711908

\section{Permanent link}

http://nrs.harvard.edu/urn-3:HUL.InstRepos:16953388

\section{Terms of Use}

This article was downloaded from Harvard University's DASH repository, and is made available under the terms and conditions applicable to Other Posted Material, as set forth at http:// nrs.harvard.edu/urn-3:HUL.InstRepos:dash.current.terms-of-use\#LAA

\section{Share Your Story}

The Harvard community has made this article openly available.

Please share how this access benefits you. Submit a story.

\section{Accessibility}


62. Resnick, R. H., Colman, R., London, A., and Richter, H. Abnormal Schilling test corrected by intestinal juice: report of case. Neu Eng. J. Med. 268 : 926-929, 1963.

63. Hogan, W. J., Soergel, K. H., and Arnaud, S. B. Transient selective vitamin $\mathrm{B}_{12}$ malabsorption in adult. Ann. Int. Med. 60:665 672,1964 .

64. Veeger, W., Abels, J., Hellemans, N., and Nieweg, H. O. Effect of sodium bicarbonate and pancreatin on absorption of vitamin $\mathrm{B}_{12}$ and fat in pancreatic insufficiency. New Eng. J. Med. 267:1341-1344, 1962.

65. Editorial. "Releasing factor" and vitamin $B_{12}$ absorption. New Eng. J. Med. 268:955, 1963.
66. Weaver, J. A., and Neill, D. W. Amino-aciduria in pernicious anaemia and subacute combined degeneration of cord. Lancet 1:1212, 1954

67. Miller, O. N., Raney, J. L., Hansen, H. J., and Troncale, F. J. Studies on interaction of vitamin $B_{12}$, intrinsic factor and receptors. II. Possible absorption of intrinsic factor. Arch. Biochem. 100:223236,1963

68. Jadhav, M., Webb, J. K. G., and Vaishnava, S. Vitamin $\mathbf{B}_{12}$ deficiency in Indian infants: clinical syndrome. Lancet 2:903-907, 1962.

69. Wegelius, R., and Malm. E. Cited by Gräsbeck et al. ${ }^{7}$

70. Quinby, W. C., Jr., and McGovern, J. J. Surgical correction of defective absorption of vitamin $\mathrm{B}_{12}$ in child. New Eng. J. Med. 259: $755-760,1958$.

\section{MEDICAL INTELLIGENCE}

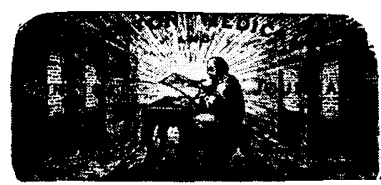

\section{INHERITANCE IN HUMAN DIZYGOTIC TWINNING*}

\author{
Colin White, M.B., B.S.,† and \\ Grace Wyshak, Ph.D., M.S. Hyg. \\ NEW HAVEN, CONNEGTIGUT
}

$\mathrm{T}$ HIS paper is concerned with the question of whether the father plays any part in the occurrence of twins among his children. Stern ${ }^{1}$ has pointed out that "the genetic interpretation of typical dizygotic twinning is complicated by the astonishing results of several studies which indicate that the disposition towards dizygotic twinning is also found in males." In one of these studies ${ }^{2}$ the rate of twinning was so high that one may conclude that many singleton births were not counted; and the apparent effect of the father on twinning can therefore be regarded as due to a bias that resulted in less complete histories, so far as singleton births are concerned, about the father's relatives than about the mother's. However, this bias is not obviously present in the work of Greulich, ${ }^{3}$ whose findings are cited by Stern. Greulich obtained data on 273 pairs of dizygotic twins. The sibs of the fathers of these twins themselves had twins in 46 out of 1851 births (2.48 per cent) whereas the sibs of the mothers had twins in only 44 out of 2020 births (2.17 per cent). It seemed, therefore, that the genotype of the father is at least as important as that of the mother in the production of dizygotic twins.

Not all the earlier authors obtained results agreeing with those of Greulich; Weinberg, ${ }^{4}$ for example, in his classic investigation, found that dizygotic twinning was hereditarily determined only

*From the Department of Epidemiology and Public Health, Yale University School of Medicine.

†Professor of biometry. Yale University School of Medicine.

${ }_{\ddagger}$ Research associate, Yale University School of Medicine. through the mother's side. Nevertheless, in view of Greulich's finding, we have obtained further data on this problem, using a method that does not depend on histories reported by probands.

\section{Data}

The data were obtained from genealogic records on file at the Genealogical Society of the Church of Jesus Christ of Latter Day Saints at Salt Lake City, Utah. The records used were the family record sheets described by Gardner, Harland and Smith. ${ }^{5}$ A single record contains information about the children borne by a specified woman to a specified husband. There are more than 4,000,000 such records, the majority being based on families formed in the eighteenth and nineteenth centuries. The record on each family lists the children in order and gives, for each child, the name, date of birth, sex, place of birth and, when applicable, the name of the spouse. It was helpful for purposes of the present project to find that each record carried a notation indicating whether a child appeared as the mother or father of a family listed elsewhere in the Archives, for this information facilitated the tracing of the family from one generation to the next.

The family record sheets were searched systematically to provide cases in which a family included twins, at least one of whom was known to have married, and whose family sheets were also on file in the Archives. Such twins constituted the index cases. A search was made for the record sheets that listed their children and also for the family record sheets of sibs of the index twins. There were 2504 eligible index twins in the sample studied so far. They were classified by the sex of the twin and the co-twin, and by a relevant feature of their record as parents - namely, the number of maternities experienced and the number of sets of twins born to them. Similar information was obtained about the sibs of the index twins.

\section{Analysis}

Twinning rates were computed as the number of sets of twins per 1000 maternities. The results obtained when the parents were themselves twins are given in Table 1. 
TABLE 1. Number of Maternities, Number of Sets of Twins and Twinning Rate when One of the Parents Is an Index Twin from a Pair of Specified Sex.

\begin{tabular}{|c|c|c|c|c|c|}
\hline $\begin{array}{l}\text { SEX OF } \\
\text { INDEX } \\
\text { TWIN }\end{array}$ & $\begin{array}{c}\text { SEX of } \\
\text { Co-TwIN }\end{array}$ & $\begin{array}{c}\text { No. of } \\
\text { INDEX } \\
\text { TwiNS }\end{array}$ & $\begin{array}{c}\text { No. of } \\
\text { MATER- } \\
\text { NITIES }\end{array}$ & $\begin{array}{c}\text { No. of } \\
\text { SETS of } \\
\text { TwINS }\end{array}$ & $\begin{array}{c}\text { TwINNINO } \\
\text { RATE } \\
\begin{array}{c}\text { per } 1000 \\
\text { mater- } \\
\text { nities }\end{array}\end{array}$ \\
\hline $\mathbf{M}$ & $\mathbf{M}$ & 948 & 4767 & 60 & 12.6 \\
\hline $\mathbf{M}$ & F & 586 & 2914 & 23 & 7.9 \\
\hline $\mathbf{F}$ & $\mathbf{M}$ & 365 & 1522 & 26 & 17.1 \\
\hline F & $\mathrm{F}$ & 605 & 2621 & 28 & 10.7 \\
\hline Both sexes & Both sexes & 2504 & 11824 & 137 & 11.6 \\
\hline
\end{tabular}

It is clear that a male twin had a considerably higher probability of appearing in subsequent records as a parent than a female did, since the data cover 1534 male index twins and only 970 female twins. However, there is no reason why this should be related to the twinning rates found in the families of the twins who were followed. The overall twinning rate of 11.6 is appropriate for the population under study. One may compute the approximate standard error of each rate as:

$$
\mathbf{r} / \sqrt{\mathbf{n}}
$$

where

$$
r=\text { the rate under consideration }
$$

and $\mathrm{n}=$ no. of sets of twins on which it is based.

The rate for a female twin parent who is a member of a dizygous set of twins is high (17.1, with a standard error of 3.4) whereas that for a male twin parent who is also a member of a dizygous set is the lowest of all four rates (7.9, with a standard error of 1.6). The difference is statistically significant, and the comparison of these two rates provides a direct test of the unimportance of the male parent in determining the occurrence of twinning in the offspring. The remaining two rates, which are included for completeness, but not discussed further in this report, are based on cases in which some of the parents were from dizygous sets of twins and some from monozygous. The current view is that monozygous twinning is not inherited. ${ }^{6}$

The twinning rates of the sibs of twins, reported in Table 2, throw further light on this problem.

TABLE 2. Number of Maternities, Number of Sets of Twins and Twinning Rate when One of the Parents Is a Sib, Male or Female, of Twins of Specified Sex.

\begin{tabular}{cccccc}
\hline $\begin{array}{c}\text { SEX of } \\
\text { INDEX } \\
\text { SiB }\end{array}$ & $\begin{array}{c}\text { SEX of } \\
\text { TwinS }\end{array}$ & $\begin{array}{c}\text { No. of } \\
\text { INDEX } \\
\text { SIBS }\end{array}$ & $\begin{array}{c}\text { No. of } \\
\text { MATER- } \\
\text { NITIES }\end{array}$ & $\begin{array}{c}\text { No. of } \\
\text { SETS of } \\
\text { TwINS }\end{array}$ & $\begin{array}{c}\text { TwINNING } \\
\text { RATE } \\
\text { per 1000 } \\
\text { mater- } \\
\text { nities }\end{array}$ \\
M & MM & 946 & 5215 & 55 & 10.5 \\
M & MF & 842 & 4421 & 58 & 13.1 \\
M & FF & 532 & 2796 & 37 & 13.2 \\
F & MM & 484 & 2161 & 23 & 10.6 \\
F & MF & 528 & 2300 & 39 & 17.0 \\
F & FF & 415 & 1841 & 19 & 10.3 \\
ALL & ALL & 3747 & 18734 & 231 & 12.3 \\
\hline
\end{tabular}

A sib of dizygous twins would presumably have the same probability of inheriting the dizygous twinning gene or genes as the twins themselves. If such genes can be expressed through the female but not through the male, the twinning rate should be raised in the families of female sibs of unlike-sexed twins but not in the families of male sibs. This finding is shown in the results presented in Table 2 although the difference between the relevant rates (17.0 and 13.1) is not significant in the statistical sense. Since like-sexed twins include both dizygous and monozygous pairs, the sibs of these twins should have a twinning rate lower than that for the female sib of unlike-sexed twins. This was in fact observed: the rates for male sibs of MM twins (10.5), male sibs of FF twins (13.2), female sibs of $\mathbf{M M}$ twins (10.6), and female sibs of FF twins (10.3) were in each case lower than those for the female sibs of unlike-sexed twins (17.0). Finally, one would expect the male sibs of like-sexed pairs to show lower rates than the female sibs of such pairs. This is true in the comparison of the sibs of MM pairs, but not in the comparison of the sibs of FF pairs. The differences are small in either case, but this is not surprising in view of the facts that the groups being compared are heterogeneous for zygosity and the standard errors involved are large.

To obtain the most comprehensive test of the role of the father, the data from twins may be combined with those from their sibs. If the comparison is restricted to cases in which the twins were of different sex, and hence known to be dizygous, it is found that the offspring of the males include twins in 81 out of 7335 maternities (11.0 per 1000) and the offspring of the females in 65 out of 3822 maternities $(17.0$ per 1000$)$. The difference in rate is 6.0 , and its standard error 2.45 ( $p$ less than 0.05 ).

\section{Discussion}

The conclusion drawn from these data is that female twins from dizygous pairs, and female sibs of such twins, show an increased twinning rate among their own offspring, but that male twins from dizygous pairs and male sibs of such pairs do not show this increased rate. The results are consistent with those of Waterhouse, ${ }^{7}$ who, in a self-selected sample of respondents, found 11 sets of twins in 122 maternities when the mother was a dizygous twin and 1 set in 66 maternities when the father was a dizygous twin. Evidence of an altogether different type, but supporting the same conclusion, has recently been obtained by Morton, ${ }^{8}$ who studied the children of interracial crosses in Hawaii. He found that the frequency of twinning is independent of the father's race but. is greatly influenced by the race of the mother. One is led to conclude that the findings of Greulich on the father's role in twinning, like those of Davenport, are probably due to less 
complete ascertainment of singleton births in the male line than in the female. It is noteworthy that Greulich's rate of twinning in the male line of monozygotic twins is somewhat high - namely, 16.1 per 1000 maternities.

\section{Conclusions}

When women who are dizygous twins become parents they produce twins at the rate of 17.1 sets per 1000 maternities. On the other hand, the wives of men who are dizygous twins have a twinning rate of only 7.9 per 1000 maternities. The female sibs of dizygous twins behave like female twins, and the male sibs like male twins, so far as the frequency of twins among the offspring is concerned. These data are consistent with the hypothesis that the genotype of the mother affects the frequency of dizygous twinning but that of the father does not.

\section{REFERENCES}

1. Stern, C. Principles of Human Genetics. Second edition. $753 \mathrm{pp}$ San Francisco: Freeman, 1960. P. 542.

2. Davenport, C. B. Is there inheritance of twinning tendency from father's side? In Verhandlungen des 5 Internationalen Kongresses fïr Vererbungswissenschaft. Edited by $\mathrm{H}$. Nachtsheim. 2 vol. Vol. 1. Leipzig: Bornträger, 1928. Pp. 595-602.

3. Greulich, W. W. Heredity in human twinning. Am. J. Phys. Anthropol. 19:391-431, 1934.

4. Weinberg, W. Beiträge zur Physiologie und Pathologie der Mehr lingsgeburten beim Menschen. Pflüger's Arch. f.d. ges. Physiol. 88 346-430, 1901

5. Gardner, D. E., Harland, D., and Smith, F. A Basic Course in Genealogy. Vol.' 1. 399 pp. Salt Lake City: Book Craft Inc., 1960. Pp. 39-201.

6. Stern. ${ }^{2}$ P. 541.

7. Waterhouse, J. A. H. Twinning in twin pedigrees. Brit. J. Social Med. 4:197-216, 1950 .

8. Morton, N. E. Genetics of interracial crosses in Hawaii. Eugenic Quart. 9:23, 1962.

\section{BRIEF RECORDING}

\section{Stupor, Hypercalcemia and Carcinoma of the Renal Pelvis*}

\author{
Hal H. Bourne, M.D., $\dagger$ \\ Righard E. Tremblay, M.D., $\ddagger$ ANd \\ Julian S. Ansell, M.D. $\S$
}

SEATTLE, WASHINGTON

\section{$S^{\prime}$}

INCE Albright ${ }^{1}$ suggested that some tumors "might be producing parathyroid hormone," hypercalcemia associated with malignant tumors without bony metastases has been recorded with increasing frequency..$^{2-5}$ Transitional-cell carcinoma of the renal pelvis is here added to the list of neoplasms that hypercalcemia may accompany.

\footnotetext{
*From the Division of Urology, Department of Surgery, University of Washington School of Medicine, and the Veterans Administration Hospital.

† Senior resident in urology, Division of Urology, University of Washington Affiliated Teaching Hospitals.

$\ddagger$ Clinical associate, Division of Urology, Department of Surgery, University of Washington School of Medicine.

$\S$ Associate professor of urology and head, Division of Urology, Department of Surgery, University of Washington School of Medicine.
}

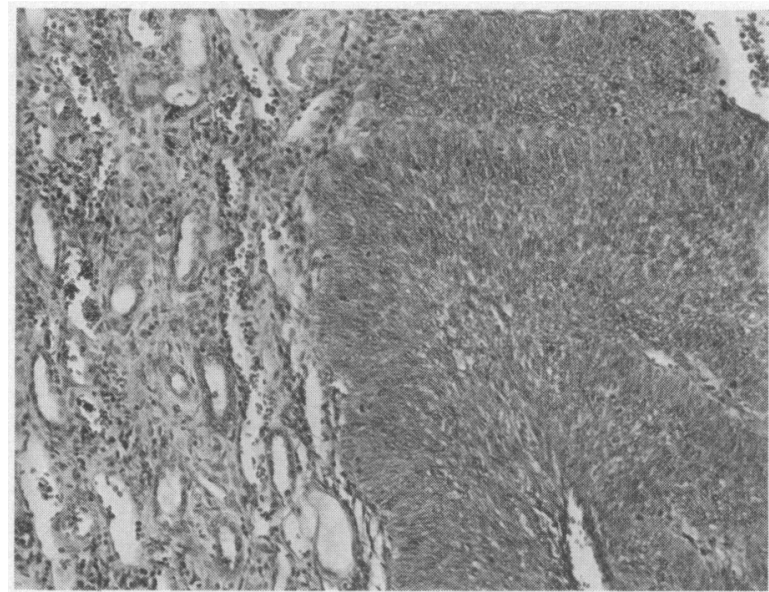

Figure 1. Microscopical Section of the Kidney, Showing a Transitional-Cell Carcinoma.

\section{Case Report}

A 69-year-old oyster farmer entered the hospital in stupor. In 1918 he had received a shrapnel wound to the right kidney, and in 1930 a right-sided staghorn calculus had been demonstrated. During the year before admission progressive anorexia, nausea, vomiting, constipation, weight loss, episodic chills and fever, lassitude, confusion, inappropriate behavior and finally progressive somnolence were noted. His condition deteriorated until he was bedfast.

Physical examination showed an afebrile, cachectic and disoriented man with marked postural hypotension. A smooth mass was felt in the right flank.

Urinalysis indicated gross pyuria, hematuria and proteinuria. The hematocrit, white-cell count, blood urea nitrogen and alkaline and acid phosphatases were normal. Serum calcium levels were 16.9 and $14.8 \mathrm{mg}$., and the serum phosphorus $3.4 \mathrm{mg}$. per $100 \mathrm{ml}$. The urine was sterile.

Intravenous urography revealed a nonfunctioning right kidney containing a staghorn calculus and a metal fragment. The left kidney was hypertrophied but otherwise normal. Retrograde pyelography showed a dilated right ureter deviated medially by a large mass in the lower pole of the kidney. A bone survey, including the hands, demonstrated slight osteoporosis.

At nephroureterectomy a pyonephrotic right kidney was found containing the staghorn calculus and a transitionalcell carcinoma of the renal pelvis (Fig. 1).

After operation the stupor cleared rapidly. The serum calcium was $9.6 \mathrm{mg}$. per $100 \mathrm{ml}$. 1 week after operation. In the 2 years since the nephrectomy the patient has been well.

\section{Drscussion}

The hypercalcemia associated with some malignant tumors can threaten life, contributing greatly to the morbidity, and perhaps cloud the clinical picture. With increased observation of this combination of hypercalcemia and malignant tumors, interest in the mechanisms linking these two entities has been stimulated.

Four explanations have been suggested: there are unrecognized metastases to bone; the tumor produces a substance with activity like that of vitamin $\mathrm{D}$; the tumor secretes a parathyroid-stimulating agent; and the tumor elaborates a substance with activity like that of parathyroid hormone. 